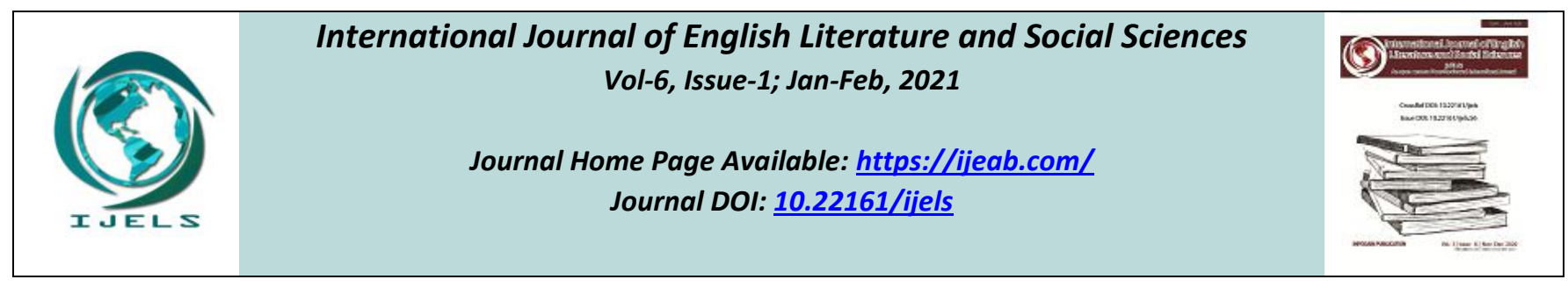

\title{
The Angel, the witch and the inscrutable wretchedness of the Patriarchal World
}

\author{
Ritobina Chakraborty
}

Department of English Literature, St. Xavier's University, Kolkata, India

Received: 03 Nov 2020; Received in revised form: 05 Jan 2021; Accepted: 11 Jan 2021; Available online: 20 Jan 2021

(C)2021 The Author(s). Published by Infogain Publication. This is an open access article under the CC BY license

(https://creativecommons.org/licenses/by/4.0/).

\begin{abstract}
The paper seeks to study the transition of connotations applied to women by taking into account, mythology, Victorian Poetry, Critical works of the $20^{\text {th }}$ Century and examples from history, digital world and media in contemporary $21^{\text {st }}$ Century. The construction of adjectives has been a Patriarchal tool. In this paper an evolution of the space of woman which led to idealizing the female sex at the cost of complete oppression is scrutinized. How deterring from the conception of the perfect woman, as formed by men, made it absolutely compulsory to eradicate the threat from society for preservation of the Patriarchal hierarchy. The terms have shifted from fear to revolution to intrigue by continuously being a threat through centuries. In the $21^{\text {st }}$ Century the threat has become a statement to reinforce agency. The disparity between the "angel" and the "witch"' is negated as an instrument to dismantle Patriarchy.
\end{abstract}

Keywords-Angel, Witch, Friedrich Engels, Victorian, Mythology.

\section{INTRODUCTION}

Feminists across generations and world have raised their voices time and again, be it the Suffrage movement, the Irish movement demanding equal wages or the outrage that brought almost every woman of Poland on the streets to protest against the Anti-Abortion Bill in 2020. Of all the movements one thing that has been common is the enemy, a dire need to dismantle aspects of Patriarchy, if not the whole system at a time. This paper attempts to scrutinize a journey of conception centering women from the Victorian age to the $21^{\text {st }}$ century and end with an envisioned Utopia.

The Victorian age is ladened by the submissive devoted image of the woman, and the literature of the age reflects the notion of how a woman is supposed to be in a heterosexual normative world. Coventry Patmore in his popular poem The Angel in The House upholds his wife, Emily, which is a commentary on the idealized woman figure. Patmore's poem was published in 1854 followed by The Espousalsin 1856, 'faithful forever'.

' Man must be pleased; but him to please

Is woman's pleasure; down the gulf

Of his condoled necessities
She casts her best, she flings herself.",

The above lines emphasise on the image of the woman who ''must please men'. Her pleasure lies in the pleasure of the man. She must cast herself to be the "'angel' in the house. The painted picture of the perfect wife therefore becomes the patriarchal construct, adept in the domestic space but completely helpless with matters that lie outside the threshold of the house. Friedrich Engels in The Origin of the Family, Private Property and the State (1884) retraces the space and identity of women to the "Primitive Age" and makes technology accountable for the ultimate physical limitation of women. He states "the overthrow of mother right was the world-historic defeat of the female sex". Engels elaborates further to say that in the primitive age women's domestic works included pottery making, weaving, gardening which appropriated women's importance in economic life. But with the discovery of metals like bronze and copper which enhanced technological invention, for instance the invention of plow, made labour power intrinsic which caused the domestic works to lose importance when compared to a man's productive work. This further facilitated the expansion of agricultural lands by clearing forests. Based on the virtue 
of physical strength men became concentrated outside the domestic space while women started concentrating more inside the house. The family structure developed according to Engels when men started owning lands, developed the owner and slave equation and extended the professional equation into the domestic. Men became the proprietor of women, the instrument of reproductivity. The word 'family' is derived from the Latin term "famulus" which means household slave making the patriarch the inexorable owner of the house and its members, the child who must be entitled to the father. Women became limited by space, economy and identity as dictated by the patriarch. The heterosexual family structure developed as a result of property ownership. Patmore's poem is a poetic appropriation of Engel's conception. Patmore not only adheres to it but establishes it as the ultimate moral code of conduct for a woman.

It is also the Victorian Period when characters like "Bartha Mason' culminates who has to after all die to preserve the image of the "Angel', The "'madwoman', has to be filtered out of literature and inevitably from the society. The concept of madness has changed considerably through the decades. During the Early Modern Period and the popular practice of witch hunting, a witch was a nonconformist to the state, religion and the norms set by the society. It was essential for the administrative elite to proliferate in the minds of the common the prejudices which would sanctify the hunt and inevitable murder of the witch. The all male administration and the women prosecuted further establishes the patriarchal construct associated with the idea of witch and practice of witch hunt.

In a 2019 Mercedes Benzadvertisement titled Bertha Benz: The Journey That Changed Everything. The advertisement depicts the life of Bertha Benz, wife of Karl Benz. She was the first woman to make the longest journey of $106 \mathrm{~km}$ from Mannheim city, her residence to her parent's house in Pforzheim driving an automobile in 1888. The advertisement begins with a group of exhausted women drawing carts when suddenly they stop. Some of them begin to pray, while others turn away and a little girl runs to inform the villagers that "'a witch" has been spotted. The "witch", wearing an emerald green gown and hat is shown driving an automobile with her two sons beside her. Most of the men and women are intrigued by her, they approach and crowd the streets with fear as many lock doors and windows to keep the "witch" away, bells are rung and a priest runs to save the day. It is in the middle of the streets when her automobile stops. More than the wagon not driven by horse what amuses people is the woman driving it. Men try to touch her, spit and laughbut none extend a hand of help. The advertisement ends with
Bertha using ten litres of ligroin from a pharmacy to refuel her automobile and drive away. The advertisement reflects the ideologies prevalent in the Victorian Period. Bertha becomes a striking contradictory figure when compared to Patmore's idealised 'Angel', and hence becomes the "witch".

Not much has changed through the ages. During the 2016 US Presidential Election the internet was swarmed with multifarious images of Hillary Clinton wearing hats, riding brooms and having green skin. Her opponents called her a Witch and accused her of smelling like Sulphur. In 2020 there was an outrage all over India when a reporter made a derogatory comment on Bengali women. Bengali women were openly accused of being witches and practicing witchcraft. The nature of the witch in this case was directly associated with economy. A man was shown as a pawn falling prey to lustful, avaricious women or the "witch". Here prejudice amalgamates with the socio-economic condition and the heterosexual family structure where the economic dependence of a woman on a man is redirected against her. The connotation "witch" here resonates "'whore', the image of a seductive woman luring innocent men and entrapping them prevalent in the folklores that has percolated to the $21^{\text {st }}$ century taking the shape of ideology. It is implanted in the unconscious to associate both the terms with women. Hence, it is Patriarchy which not only sets the codes of conduct but also the politics of language. Words become involuntarily gendered and derogatory.

Both Eastern and Western Mythologies bear witness of women facing wrath of gods and goddesses when they were the victims. Ahalya was seduced by Indra in the disguise of her husband. On learning, Sage Gautama Maharishi, Ahalya's husband abandoned her and accused her of infidelity. She was ostracised and cursed. Ahalya turned into stone and was only liberated from the curse by Ram's touch. Her entire existence was entitled by men. It was men who cursed and liberated her. She had no agency for herself. The Myth of Medusa is another instance where the victim was turned into a monster or a 'witch". Medusa was ravaged by Poseidon in Athena's shrine. Athena enraged by the act cursed Medusa and turned her hair into snake, which would turn anybody into stone if looked at. What makes the second myth interesting is how a woman is cursed by another woman when it was a man who committed the crime. Patriarchal regime has implemented in the minds of women an idealised vision of themselves. A woman is thus projected against another woman. Bartha Mason has to stand against Jane Eyre to establish Jane as the ideal woman. A woman thus involuntarily becomes another woman's enemy because she has to fit in to the patriarchal construct of the "Angel in The House". In an 
American sitcom called 'FRIENDS', a character named Rachel Green says that "women tend not to like' her. The generalised observation reiterates the fact that women unconsciously develop an instinct to compete against another women to establish superiority, which is acknowledgement by the men of the society.

During the World War II a group of all women military aviators were popular by the name of "Night Witches". Major Marina Raskova obtained permission from Joseph Stalin to form the $588^{\text {th }}$ Night Bomber Regiment. They dropped 23,000 tons of bombs to become a crucial Soviet asset. The Germans named them "Nachthexen" or the "night witches" as the noise of the aircrafts in the darkness of night resembled the sound of sweeping brooms.

"This sound was the only warning the Germans had. The planes were too small to show up on radar... [or] on infrared locators, " said Steve Prowse, author of The Night Witches, a nonfiction account of the little-known female squadron. "They never used radios, so radio locators couldn't pick them up either. They were basically ghosts. ',

The statement above is a perfect example of how women defying the image of conformists, domestic, helpless automatically becomes a threat. Myth, history, patriarchy and prejudice convey the idea that a woman must be feared if she denies limitation both physical and emotional as set by men. A "witch" is dangerous, one who cannot be perceived. Therefore, as women started breaking conventions and their actions became their agency of existence, women blurred the gap between the prevalent concepts of the "'angel" and the "witch". For the Soviets these women became angelic, bringing victory. While for the Nazis they became the untraceable "witches".

From myth to history to the present day, a woman has become a witch inevitably whenever she denied conformity to Patriarchal norms. Witches in the $21^{\text {st }}$ century have evolved to emancipation. It is a statement of agency, a title of reinforce their power. Per Faxneld in Satanic Feminism: Lucifer as the Liberator of Women in Nineteenth Century Culturewrites that Women are Satan's chosen ones. Jules Michelet in La Sorciere(1862), says, that Satan lays 'the fruit of science and of nature' in the hands of a woman. In Renaissance England anybody who practiced magic which was not sanctioned by the church became the Witch. These Witches knew what in the modern day is practiced as Ayurveda, treatments with natural herbs. Often, they aided women undergoing labour, their knowledge eased the pain. In contradiction to Per Faxneld this aid was considered a sin. The damned woman must go through the pain to achieve salvation, to please
God. Therefore, the witch's adept in science became a threat that must be eradicated.

\section{CONCLUSION}

Taking the present situation under consideration, the figure of the "witch" has become extremely popular. A number of web series and fantasy fictions have invested in debunking the stereotypes associated with witches. Unlike Macbeth's witches who are ragged, hideous and ignoble, the jovial, immortal witches of the Netflix series, Chilling Adventures of Sabrina, journeys from innocence to experience, maintains a balance between her mortal teenage life and her life amidst witches and wizards. She aids humans in need and at the same time protests against what she considers wrong in the world of Witchcraft and Satanism. There is a sense of inclusion in the Academy of Unseen Arts, the school of witchcraft Sabrina attends. Though it is not excluded from vices like bullying, witches and wizards are treated equally. The conception has changed and the eerie atmosphere is no longer despicable but intriguing with an underlying tone of acceptance than eradication. Dressing up in a gothic fashion have become a style statement. Women have started calling themselves witches with pride, a statement against the Patriarchal rules.

The theory of Posthumanism can be perceived as a perfect reply to ages of disparity. The "'Gender-less" promise of a world which would be inclusive of ' man, woman and the other', only the "'other' will cease to exist. The gender conforming expectations like women subjected to reproduction would advance technologically and even man, would be able to conceive and reproduce. A posthuman anti natural world would then become a safe space for women where she neither has to be an 'angel' or become a "witch" to simply exist. The vision of Utopia then becomes the ultimate desire which can be achieved through technology. Therefore, the apple which can be a metaphor for technology in the hands of a woman becomes the ultimate baton for the creation of a space where the angel and the woman merges to become an entitled being, a response to shatter the inscrutable wretchedness of the Patriarchal World.

\section{REFERENCES}

[1] The Angel in The House, Coventry Patmore

[2] Bertha Benz: The Journey That Changed Everything, Mercedes Benz advertisement 2019

[3] The Origin of the Family, Private Property and the State, Friedrich Engels

[4] From Circe to Clinton: why powerful women are cast as witches, The Guardian 
[5] Friends, American Sitcom

[6] Satanic Feminism: Lucifer as the Liberator of Women in Nineteenth Century Culture, Per Faxneld

[7] Meet the Night Witches, the Daring Female Pilots Who Bombed Nazis By Night, History.com

[8] Chilling Adventures of Sabrina, Netflix 